\title{
Microbenthos in a hypersaline tidal lagoon: factors affecting microhabitat, community structure and mass exchange at the sediment-water interface
}

\author{
J. García de Lomas*, A. Corzo, C. M. García, S. A. van Bergeijk \\ Depto. Biología (Área Ecología), Facultad de Ciencias del Mar y Ambientales, Pol. Río San Pedro s/n, \\ 11510 Puerto Real (Cádiz), Spain
}

\begin{abstract}
Three benthic microbial communities from a hypersaline lagoon with tidal influence were studied: a compact microbial mat, a 'fluffy' microbial mat and a non-cohesive diatom-dominated sediment. In each community, qualitative and quantitative analyses of phototrophs, meio- and macrofauna were done. Vertical profiles of oxygen, sulfide and $\mathrm{pH}$ were measured at the sediment-water interface using microelectrodes. Physico-chemical properties of the water column were also assessed. The most compact mat, dominated by Microcoleus chthonoplastes, had the highest photosynthetic biomass, while meio- and macrofauna were nearly absent. The compact mat showed the steepest physico-chemical microgradients and the highest fluxes of oxygen and sulfide. The 'fluffy' mat had an areal amount of chl a similar to the compact mat and contained a higher abundance of meiofauna. This mat showed the deepest oxic layer. The diatom-dominated sediment comprised a high abundance of macrofauna, but meiofauna were very scarce. This community presented relatively smoother microgradients and intermediate values of internal fluxes of oxygen. Our results show the close relationship between the structure of the microbenthic communities, net metabolism, and the exchange of mass at the water-sediment interface. Changes in biotic and abiotic factors determined the spatial distribution of each microbial community.
\end{abstract}

KEY WORDS: Microbenthic community $\cdot$ Microbial mat $\cdot$ Meiofauna $\cdot$ Macrofauna $\cdot$ Microelectrodes Biotic factors $\cdot$ Abiotic factors

\section{INTRODUCTION}

Microbenthic communities play a major role in the flux of carbon in shallow aquatic environments. These complex microbial communities are vertically stratified, and the organisms growing herein are subjected to steep physico-chemical microgradients (Jørgensen et al. 1983, Revsbech et al. 1983). Biomass, species composition and physical structure of microbenthic communities are highly variable. These communities can vary from those inhabiting the surface of noncohesive sediments, where the microbial community is invisible to the naked eye, to very well-developed and conspicuous microbial mats that form a continuous biofilm on the sediment surface. Given the trophodynamic importance of these kinds of microbial commu- nities in intertidal flats and other shallow aquatic environments and their role in the exchange of nutrients at the water-sediment interface, it is necessary to understand the ecological factors that determine their abundance and structure in nature. Moreover, biomass density, species composition and the physical structure of microbenthic communities are likely to strongly affect the overall nutrient cycling. Similarly, the physical stability of sediment is also affected by species composition: aggregation and compactation may occur by exopolymer secretion and entangling of filamentous cyanobacteria, while mechanical disturbance of the sediment increases with the abundance of meioand macrofauna (Giere 1993). The presence of specific physiological adaptations in some taxonomic groups allows them to compete favourably in harsh environ- 
ments. Nitrogen fixation (Dubinin et al. 1992), fermentation (Moezelaar et al. 1996), the use of sulfide as an electron source (de Wit \& van Gemerden 1989, van den Hoek et al. 1995), and the presence of some UV-protective substances (Garcia-Pichel \& Castenholz 1991) have been demonstrated in some cyanobacteria, allowing these microorganisms to survive under very stressful and dynamic conditions (high irradiance, salinity, temperature). However, these physiological adaptations do not explain why microbial mats are usually absent in more moderate environmental conditions. Meio- and macrofauna can also play an important role in controlling microbial mat development in coastal environments. Under moderate environmental conditions, e.g. coastal environments, meio- and macrofauna reduce primary producer concentration due to a high grazing activity (Hargrave 1970, Connor et al. 1982), and thus these mild conditions prevent mat accretion (Jørgensen et al. 1983, Awramik 1984). It has been classically postulated that extreme conditions like high salinities in hypersaline environments (Pierson et al. 1987, Wieland \& Kühl 2000), periodic dryings (Lassen et al. 1992), or high temperatures from thermal sources (Castenholz 1984) can limit meio- and macrofauna growth, allowing the development of microbial mats. However, few studies have quantified meio- and macrofauna in microbial mats (Fenchel 1998, Pinckney et al. 2003), or analyzed their possible influence on mat structure, metabolism, and the exchange of mass at the water-sediment interface (Cullen 1973, Aller \& Aller 1992, Huettel \& Gust 1992).

In the present study, we compare 3 different types of benthic communities growing in a small hypersaline lagoon with tidal influence, and therefore under the same ecological conditions at a macroscopic scale. The lagoon is within a protected area, the Natural Park 'Bahía de Cádiz', where different types of microbenthic communities, including microbial mats, can be found. Microbenthic communities had not been studied previously in the Bay of Cádiz despite their importance in terms of surface cover in salt marshes, saltpans and intertidal sediments. This study aims to elucidate the ecological factors affecting the benthic microhabitat and its microbial community and determine how these factors can influence the community structure, metabolism and mass transfer at the watersediment interface.

\section{MATERIALS AND METHODS}

Area of study. The sampling site is a small (ca. 3 ha) and very shallow (depth $<1 \mathrm{~m}$, mean values 0.15 to $0.20 \mathrm{~m}$ ) lagoon located inside the Natural Park 'Bahía de Cádiz', in the SW of Spain (36³2' 2" N, 6 12' 35" W).

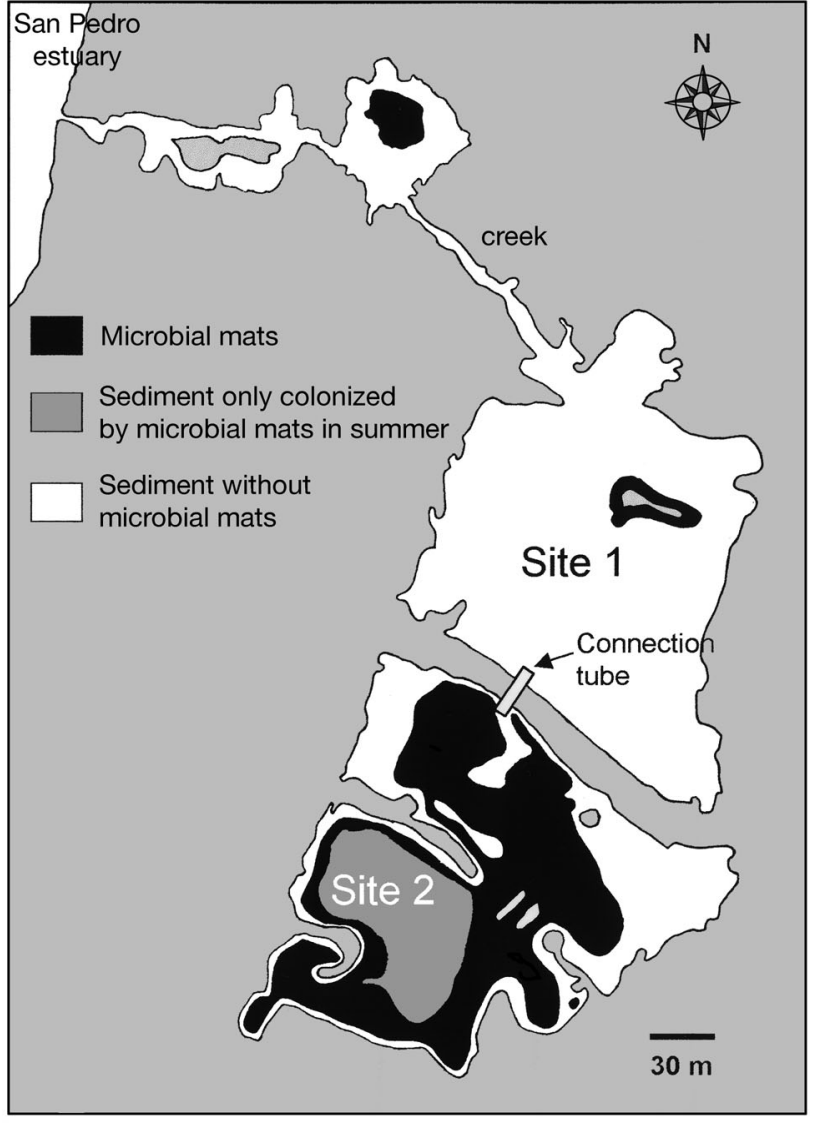

Fig. 1. Area of study in SW of Spain. Surface colonized by microbial mats in the lagoon. Microbial mats were only present in the zone furthest away from the estuary. Some sediment surface was only covered by mats during the summer (June to September)

It is connected to the San Pedro estuary by a creek, allowing a tidal input of marine water (Fig. 1), but the regime of exchange and renovation of water in the lagoon does not coincide with that of the estuary. Two different areas can be distinguished according to tidal exchange and water renovation. An artificial tube that limits water flow connects these 2 sub-lagoons. The side closer to the estuary, in the north (Site 1), has relatively moderate salinities (30-50) and higher spatial homogeneity, whereas the patchy lagoon in the south (Site 2) has a lower water turnover rate, leading to more fluctuating and extreme salinities (up to 80-100, mean value 45). Site 2 could therefore be associated with a strong physical control: longer emersion periods (up to $2 \mathrm{mo}$ ) and more frequent fluctuations with higher amplitudes of temperature, salinity and other physico-chemical variables.

The present study was done in 2 phases. In the first phase (April to June 2000), we did a general characterization of Site 1 and Site 2 to understand why microbial 
mats were mainly present at Site 2 . Once the general hydrological dynamics of the lagoon were understood, the study was focussed (April 2003) on 3 kinds of microbenthic communities present at Site 2 to better resolve what ecological factors, biotic and abiotic, determine their different structure. The smaller size of Site 2 guarantees a higher uniformity at the macroscopic scale in the physico-chemical and climatological variables to which the microbenthic communities were adapted. The studied communities were non-cohesive diatom-dominated sediment, a thick microbial mat with a fluffy appearance, and a compact microbial mat.

Hydrology and physico-chemical parameters of the water column. Characterization of the lagoon at different temporal resolutions was performed by assessing the hydrology and a number of physico-chemical variables. Near daily measurements of water level, rain-evaporation balance, salinity, $\mathrm{pH}$, water temperature, and the concentration of dissolved oxygen, nitrate and ammonium were carried out from April to June 2000. During a $12 \mathrm{~h}$ tidal cycle on 3 June 2000, water level, $\mathrm{O}_{2}, \mathrm{pH}$, and water temperature were monitored every $10 \mathrm{~min}$, using a multiparameter logger. Irradiance, rain and evaporation data were acquired from the meteorological station located at Cádiz city $(8 \mathrm{~km}$ away from the lagoon).

Organic matter content of the sediment and granulometry. Water content and the amount of organic matter were determined in sediment cores $(n=3$, inner diameter [i.d.] $=6.7 \mathrm{~cm}$ ) collected during April 2003 from each microbenthic community at Site 2 according to Krumgalz \& Fainshtein (1989). In order to analyze grain-size composition, 3 cores were taken $(\mathrm{n}=3$, i.d. $=10.5 \mathrm{~cm}$ ) from each benthic community. In the laboratory, samples (upper $5 \mathrm{~cm}$ ) were passed through a stack of sieves with 2.0, 1.0, 0.5, 0.25, 0.125, and $0.063 \mathrm{~mm}$ mesh sizes, using tap water. Through this wet sieving, salt is removed but faecal pellets are conserved, which can consolidate great amounts of fine sediment. Desiccation of the sediment, which leads to disintegration of the faecal pellets into their constituents (Giere 1993), was thus avoided. After the wet sieving, each size fraction was dried at $60^{\circ} \mathrm{C}$ for $72 \mathrm{~h}$ and subsequently weighed. A granulometric curve was obtained as cumulative percentages starting with the coarsest fraction. Several granulometric indices were calculated: sorting coefficient, graphic mean (median grain diameter, Md), and inclusive graphic skewness (Giere 1993).

Phototrophs and vertical distribution of pigments. Sediment cores $\left(\mathrm{n}=3\right.$ ) with a surface area of $4 \mathrm{~cm}^{2}$ (as recommended by Eaton \& Moss 1966) were taken from each of the benthic communities at Site 2 in April 2003 and immediately carried to the laboratory. Vertical distributions of pigments were studied in these cores by slicing thin sections $(1 \mathrm{~mm})$ of fresh sediment using a razor blade. A total of 10 sections were obtained from each core. As extractant, 100\% methanol was used (Thompson et al. 1999). Samples were sonicated (5 pulses of $30 \mathrm{~s}$ at $15 \mathrm{~W}$ ) and extracted for $24 \mathrm{~h}$ at $4{ }^{\circ} \mathrm{C}$ in the dark. Extracts were filtered and the absorption spectrum was obtained between 350 and $1100 \mathrm{~nm}$ using a spectrophotometer (Unicam UV/VIS UV2 ${ }^{\circledR}$ ). Pigment concentrations (chlorophyll a [chl a] and bacteriochlorophyll a) were estimated after Pierson et al. (1987) and results were expressed in $\mu \mathrm{g}$ of $\mathrm{chl} \mathrm{a} \mathrm{g}^{-1}$ of wet weight (ww). Taxonomic identifications of microalgae were done by light microscopy according to Bourrelly (1970, 1972, 1981), Rippka et al. (1979), Sournia (1986), Castenholz et al. (1989), Staley et al. (1989), Komárek \& Anagnostidis (1986, 1989), Round et al. (1990) and Chrétiennot-Dinet (1990). A chl a:C ratio of 1:50 was used to transform chl a concentration in C (Joint 1978).

Meiofauna and macrofauna abundance. Cores taken in April (2003) for meiofauna analyses $(n=3)$ were collected by using a $2.7 \mathrm{~cm}$ i.d. syringe with the lower end cut. Meiofauna from the upper $1 \mathrm{~cm}$ were quantified. Samples were filtered through a fine mesh of $63 \mu \mathrm{m}$ (after passing through a mesh of $500 \mu \mathrm{m}$ ) using filtered $(0.45 \mu \mathrm{m})$ seawater. Subsequently, they were fixed and mixed with $4 \%$ formaldehyde, containing $1 \mathrm{~g} \mathrm{l}^{-1}$ Rose Bengal. Numbers of individuals from different groups (Nematoda, harpacticoid Copepoda, Amphipoda, polychaetes, Ciliata and Diptera larvae) were hand-sorted under a stereoscopic microscope.

Cores destined for macrofauna analysis $(\mathrm{n}=3$, i.d. = $10.5 \mathrm{~cm}$ ) were taken from each benthic community in April (2003). The upper $5 \mathrm{~cm}$ were sieved with in situ water through a mesh of $500 \mu \mathrm{m}$ (Holme 1971). A soft brush was used to facilitate sample dislodgment through the filter (Arias \& Drake 1999). Major taxonomic groups (Diptera larvae, polychaetes, Lamellibranchia and amphipods) were hand-sorted under a stereoscopic microscope. Species were determined after Arias \& Drake (1999).

Vertical profiles of oxygen, sulfide and pH. From each microbenthic community a sample was taken in April-May (2003) with a plexiglass core tube (i.d. = $6 \mathrm{~cm}$ ) and was used for microelectrode measurements immediately upon return to the laboratory. The core tube containing the sample was placed in a temperature-controlled flow chamber (Lorenzen et al. 1995), which was filled with filtered water from the sampling site (salinity $=43$ ), and a flow of $0.55 \mathrm{~cm} \mathrm{~s}^{-1}$ was established. This was calculated as the rate of outflow divided by the water-filled cross-area of the chamber (Lorenzen et al. 1995). The water depth inside the chamber was $1 \mathrm{~cm}$. The cores were incubated at a temperature of $20 \pm 1^{\circ} \mathrm{C}$ and a photon flux density of $220 \mu \mathrm{mol} \mathrm{m} \mathrm{m}^{-2} \mathrm{~s}^{-1}$ using a halogen lamp (Novaflex, 
World Precision Instruments) for at least $1 \mathrm{~h}$ before the measurements were started. Steady-state profiles of dissolved oxygen, sulfide and $\mathrm{pH}$ were measured using microelectrodes. The microelectrodes were mounted in a micromanipulator and were lowered into the samples with a $100 \mu \mathrm{m}$ vertical step resolution.

Microelectrodes were purchased from Unisense ${ }^{\circledR}$. The oxygen sensors (Revsbech 1989) had a tip diameter of 20 to $30 \mu \mathrm{m}$, a response time of 0.2 to $0.4 \mathrm{~s}$, and a stirring sensibility $<2 \%$. Linear calibration was performed by taking $100 \%$ saturation of $\mathrm{O}_{2}$ at the well-oxygenated overlying water in the flow chamber, while $0 \%$ saturation was achieved in the anoxic layer inside the mat (Kühl et al. 1996, Epping et al. 1999). The sulfide microelectrodes had a tip diameter of 20 to $30 \mu \mathrm{m}$. Calibration was done by adding aliquots of a sodium sulfide solution (50 $\mathrm{mM}$ in $\mathrm{N}_{2}$-flushed $0.1 \mathrm{M}$ $\mathrm{NaOH}$ ) to an $\mathrm{N}_{2}$-flushed $0.1 \mathrm{M}$ phosphate buffer of pH 7 (Jeroschewski et al. 1996, Kühl et al. 1998). Oxygen and sulfide sensors were connected to a high-sensitivity picoammeter (Unisense PA2000 ${ }^{\circledR}$ ). The polarization voltage was adjusted to $-0.80 \mathrm{~V}$ for the oxygen sensor and to $+0.085 \mathrm{~V}$ for the sulfide sensor. The $\mathrm{pH}$ microelectrode had a tip diameter of $25 \mu \mathrm{m}$. This sensor was connected via a high impedance $\mathrm{mV}$-meter (MeterLab) to an external reference electrode positioned in the bulk water during the experiments. The $\mathrm{pH}$ electrode was calibrated using $0.1 \mathrm{M}$ phosphate buffers of pH 6, 8 and 10 (Revsbech \& Jørgensen 1986). All calibrations were performed at the same temperature as the measurements. When the $\mathrm{pH}$ profiles showed a significant variation $(>0.1 \mathrm{pH}$ unit), it was necessary to correct the measured sulfide profiles (Kühl \& Jørgensen 1992), whose concentration was calculated as follows:

$$
\left[\mathrm{H}_{2} \mathrm{~S}\right]=\left[\mathrm{S}_{\text {tot }}{ }^{2-}\right] /\left(1+\left(\mathrm{K}_{1} \mathrm{~K}_{2} /\left[\mathrm{H}_{3} \mathrm{O}^{+}\right]^{2}\right)+\left(\mathrm{K}_{1} /\left[\mathrm{H}_{3} \mathrm{O}^{+}\right]\right)\right)
$$

where $\left[\mathrm{S}_{\text {tot }}{ }^{2-}\right]$ is the total sulfide concentration, $\mathrm{H}_{3} \mathrm{O}^{+}$is the hydrogen ion activity, calculated from measured $\mathrm{pH}$ values. $K_{1}$ and $K_{2}$ are the first and second dissociation constants, respectively, of the sulfide equilibrium system: $\mathrm{pK}_{1}=7.05$ and $\mathrm{pK}_{2}=17.1$ (Kühl \& Jørgensen 1992).

Flux calculations. From the obtained oxygen profiles, oxygen fluxes across the sediment-water interface $(J)$ were calculated using the equation of Fick's first law of diffusion (Kühl et al. 1996):

$$
J(z)=-D_{\mathrm{o}}[-\partial \mathrm{C}(z) / \partial z]
$$

where $D_{\mathrm{o}}$ is the free solution molecular diffusion coefficient of oxygen and $[\partial \mathrm{C}(z) / \partial z]$ is the linear oxygen concentration gradient in the diffusive boundary layer above the sediment surface. Because salinity was 43, we used a $D_{\mathrm{o}}$ of $1.948 \times 10^{-5} \mathrm{~cm}^{2} \mathrm{~s}^{-1}$, which is $8 \%$ lower than the value for freshwater (Broecker \& Peng 1974, Li \& Gregory 1974). A negative flux ( $\left.J_{\text {up }}\right)$ indicates a net export of oxygen out of the sediment and represents the net areal photosynthesis $\left(P_{\mathrm{n}}\right)$ of the microbial community present; a positive flux indicates a net uptake of oxygen and represents the areal respiration $\left(R_{\text {dark }}\right)$ (Table 1).

In order to calculate the oxygen flux inside the sediment, equations also based on Eq. (2) were used (Kühl et al. 1996):

$$
\begin{gathered}
J_{\text {down }}^{\prime}=-\phi(z) \cdot D_{\mathrm{s}}(z) \cdot[-\partial \mathrm{C}(z) / \partial z]=D_{\mathrm{e}} \cdot \partial \mathrm{C}(z) / \partial z \\
\phi(x) \cdot D_{\mathrm{s}}(x)=D_{\mathrm{o}} \cdot\left[\partial C_{\mathrm{w}}(x) / \partial x\right] \cdot\left[\partial C_{\mathrm{s}}(x) / \partial x\right]^{-1}
\end{gathered}
$$

where $J_{\text {down }}$ is the oxygen flux inside the mat, $\phi(z)$ is the porosity and $D_{\mathrm{s}}(z)$ and $D_{\mathrm{e}}$ are the apparent and the effective diffusion coefficients, respectively, inside the

Table 1. Oxygen and sulfide fluxes and other parameters calculated in the 3 benthic communities studied. The variables used

\begin{tabular}{|c|c|c|c|c|c|}
\hline Parameter & Variables & Units & Sediment & Fluffy mat & Compact mat \\
\hline Areal net photosynthesis, light & $J_{\text {up }}=P_{\mathrm{n}}$ & $\mu \mathrm{mol} \mathrm{O} \mathrm{cm}^{-2} \mathrm{~h}^{-1}$ & 0.2805 & 0.1403 & 0.3506 \\
\hline Flux of $\mathrm{O}_{2}$ inside the mat, light & $J_{\text {down }}^{\prime}$ & $\mu \mathrm{mol} \mathrm{O} \mathrm{cm}^{-2} \mathrm{~h}^{-1}$ & 0.075 & $0.026^{\mathrm{a}}$ & 0.1177 \\
\hline Areal respiration, dark & $R_{\text {dark }}=J_{\text {down }}$ & $\mu \mathrm{mol} \mathrm{O} \mathrm{Cm}^{-2} \mathrm{~h}^{-1}$ & 0.1503 & 0.1252 & 0.1001 \\
\hline Volumetric dark respiration & $R_{\mathrm{dark}} / Z_{\mathrm{dark}}$ & $\mu \mathrm{mol} \mathrm{O} \mathrm{cm}^{-3} \mathrm{~h}^{-1}$ & 1.5 & 0.69 & 1.4 \\
\hline Flux of $\mathrm{H}_{2} \mathrm{~S}$, light & & $\mu \mathrm{mol} \mathrm{H}_{2} \mathrm{~S} \mathrm{~cm}^{-2} \mathrm{~h}^{-1}$ & - & - & 0.0874 \\
\hline Flux of $\mathrm{H}_{2} \mathrm{~S}$, dark & & $\mu \mathrm{mol} \mathrm{H}_{2} \mathrm{~S} \mathrm{~cm}^{-2} \mathrm{~h}^{-1}$ & - & - & 0.0798 \\
\hline Oxic layer thickness, light & $Z_{\text {light }}$ & $\mathrm{mm}$ & 4.9 & 10 & 2 \\
\hline Oxic layer thickness, dark & $Z_{\text {dark }}$ & $\mathrm{mm}$ & 1 & 1.8 & 0.7 \\
\hline $\begin{array}{l}\text { Diffusivity (porosity } \times \text { effective } \\
\text { diffusion coeficient) }\end{array}$ & $\phi \cdot D_{\mathrm{s}}\left(\times 10^{5}\right)$ & $\mathrm{cm}^{2} \mathrm{~s}^{-1}$ & 0.7891 & $\begin{array}{l}\text { UL: } 0.9209 \\
\text { DL: } 0.4898\end{array}$ & 0.4898 \\
\hline Photoautotrophic biomass & Chl a & $\mathrm{mg} \mathrm{chl} a \mathrm{~m}^{-2}$ & 172 & 689 & 721 \\
\hline Photosynthetic quotient & $\mathrm{P} / \mathrm{B}$ & $\mathrm{d}^{-1}$ & 0.093 & 0.012 & 0.028 \\
\hline Photosynthetic quotient & $P_{\mathrm{n}} / \mathrm{chl} a$ & 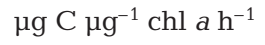 & 0.196 & 0.024 & 0.058 \\
\hline
\end{tabular}
is the same as in Kühl et al. (1996). UL: values calculated in the upper layer of the fluffy mat, but not used for calculations. DL: values expected in the downward layer, where a dense and compact band of Microcoleus chthonoplastes was found, similar in the compact mat. -: undetectable values within the upper $10 \mathrm{~mm}$ 
sediment. $\partial C(z) / \partial z$ is the concentration gradient in the lower limit of euphotic zone. The product $\phi \times D_{\mathrm{s}}$ was calculated as the ratio of the concentration gradients of oxygen concentration in water and sediment $\left(C_{\mathrm{w}}\right.$ and $C_{\mathrm{s}}$, respectively), multiplied by the molecular diffiusion coefficient in fresh water $\left(D_{\mathrm{o}}\right)$ (Revsbech 1989, Glud et al. 1995) (Eq. 4). For the determination of diffusivity, the sediment was biologically inactivated by adding formaldehyde (4\% v/v final concentration) and chemically oxidized (see Glud et al. 1995). Oxygen profiles were measured in the dark. In this way, values of $\phi \times$ $D_{\mathrm{s}}=0.7891 \times 10^{-5}, 0.9209 \times 10^{-5}$ and $0.4898 \times 10^{-5} \mathrm{~cm}^{2}$ $\mathrm{s}^{-1}$ were obtained for the sediment, the fluffy mat and the compact mat, respectively (Table 1). However, a $\phi \times$ $D_{\mathrm{s}}$ of $0.4898 \times 10^{-5} \mathrm{~cm}^{2} \mathrm{~s}^{-1}$ was used for the fluffy mat, because at the depth where $J_{\text {down }}^{\prime}$ was calculated a dense layer of Microcoleus chthonoplastes was present.

Photosynthetic and respiratory quotients of 1 were used to express photosynthesis and respiration rate in $\mathrm{C}$ units when necessary. Net carbon fixation rate during the day was calculated from the areal net photosynthesis rate, and the aerobic carbon mineralization during the night from the respiration rate in the dark, assuming a light:dark cycle of 12:12 h light:dark. The daily net primary production was calculated by subtracting carbon mineralization from carbon fixation.

Sulfide fluxes inside the fluffy and the compact mats were calculated using Eq. (3), assuming $D_{\mathrm{s}}\left(\mathrm{H}_{2} \mathrm{~S}\right)=$ $1.39 \times 10^{-5} \mathrm{~cm}^{2} \mathrm{~s}^{-1}$ as the apparent diffusion coefficient of sulfide (Kühl \& Jørgensen 1992) and the porosity close to the unit and constant with depth.

Statistical analysis. Differences in chl $a$, meio- and macrofauna among microbenthic communities (mean values) were tested by analysis of variance (ANOVA). The Tukey test was used after ANOVA to further test differences between 2 means (Zar 1984). Two-factor ANOVA was used to compare vertical distributions of chl a and oxygen among communities, using Statgraphics ${ }^{\circledR}$ Plus 5.0. In this analysis, the effects on oxygen or chl $a$ of the factors type of community and depth (as dependent variables) were statistically evaluated.

\section{RESULTS}

\section{Hydrology and physico-chemical parameters of the water column}

Tidal influence in the lagoon was clearly noted at Site 1 , where the highest water levels coincided with the highest levels of high tide (Fig. 2a). However, the water level was not only controlled by tides. The negative rain-evaporation balance in May and June (Fig. 2b) resulted in a decrease in water level and a considerable increase in salinity, which was most pronounced at Site 2
(Fig. 2c). During the monitoring period, nitrate concentration remained below $1.05 \mu \mathrm{M}$ at both stations, while ammonium varied between 2.5 and $10 \mu \mathrm{M}$ without $\mathrm{a}$ clear trend (data not shown). Measurements of water level, dissolved $\mathrm{O}_{2}, \mathrm{pH}$, and temperature during a tidal cycle (short-term measurements, Fig. 2) also revealed that tidal influence was greater at Site 1 than at Site 2, where the input of tidal water is hardly observed (Fig. 2e). A sharp change was observed in water level and water temperature at Site 1 at the moment of tidal input (Fig. 2e,f,h). Evidence of a daily cycle in both $\mathrm{O}_{2}$ and $\mathrm{pH}$ were observed at both sites (Fig. 2f,g). $\mathrm{O}_{2}$ in the water column was undersaturated in the morning (20 to $50 \%$ ) and supersaturated during the afternoon (100 to $150 \%$ ).

\section{Spatial distribution of benthic microbial communities}

Spatial distribution of different communities in the lagoon was not homogeneous (Fig. 1). Microbial mats covered a large area at Site 2 (about $50 \%$ in winter and about $65 \%$ in summer), where tidal influence was lower and therefore more prone to seasonal salinity changes and periodic desiccation. Microbial mats were also present in small areas closer to the San Pedro estuary. These sites were located well above sea level, and tidal water input was restricted to the biggest tides. The aspect of surface and physical structure of the microbenthic communities studied at Site 2 differed considerably (Fig. 3). Moreover, a clear zonation was observed in the spatial distribution of these communities along a transect from the center of the lagoon to the emerged shore (Fig. 4). The inner part of the lagoon was covered by lax diatomdominated sediment without mat structure (Fig. 3a) with an overlaying water column of about $15 \mathrm{~cm}$. This sediment had a loose appearance and its surface comprised plenty of tubes from amphipods and polychaetes. A fluffy microbial mat covered a band closer to the shoreline at a mean depth of $6 \mathrm{~cm}$ and showed a 4 to $5 \mathrm{~mm}$ thick surface, fluffy layer (Fig. 3b). Compact-laminated microbial mats (Fig. 3c) mainly appeared in the lagoon fringes (about $3 \mathrm{~cm}$ depth), where the emersion-flood episodes were more frequent and/or water salinity reached higher values. Each of these 3 communities represented different autotrophic biomass inhabiting the sediment surface. To emphasise this, we measured total chl a per unit area in a short transect along a steep shore (Fig. 5). The mats covered wider fringes where the slope was less pronounced, as they appeared in the water level fluctuation zone, i.e. in the fringe that is not permanently but only periodically flooded.

The sediments at Site 2 were mainly composed of fine sand $(\mathrm{Md}=0.19 \mathrm{~mm})$. Some differences were observed between communities (Fig. 6), such as a higher mean grain size in both microbial mats $(\mathrm{Md}=0.23$ and $0.35 \mathrm{~mm}$ 

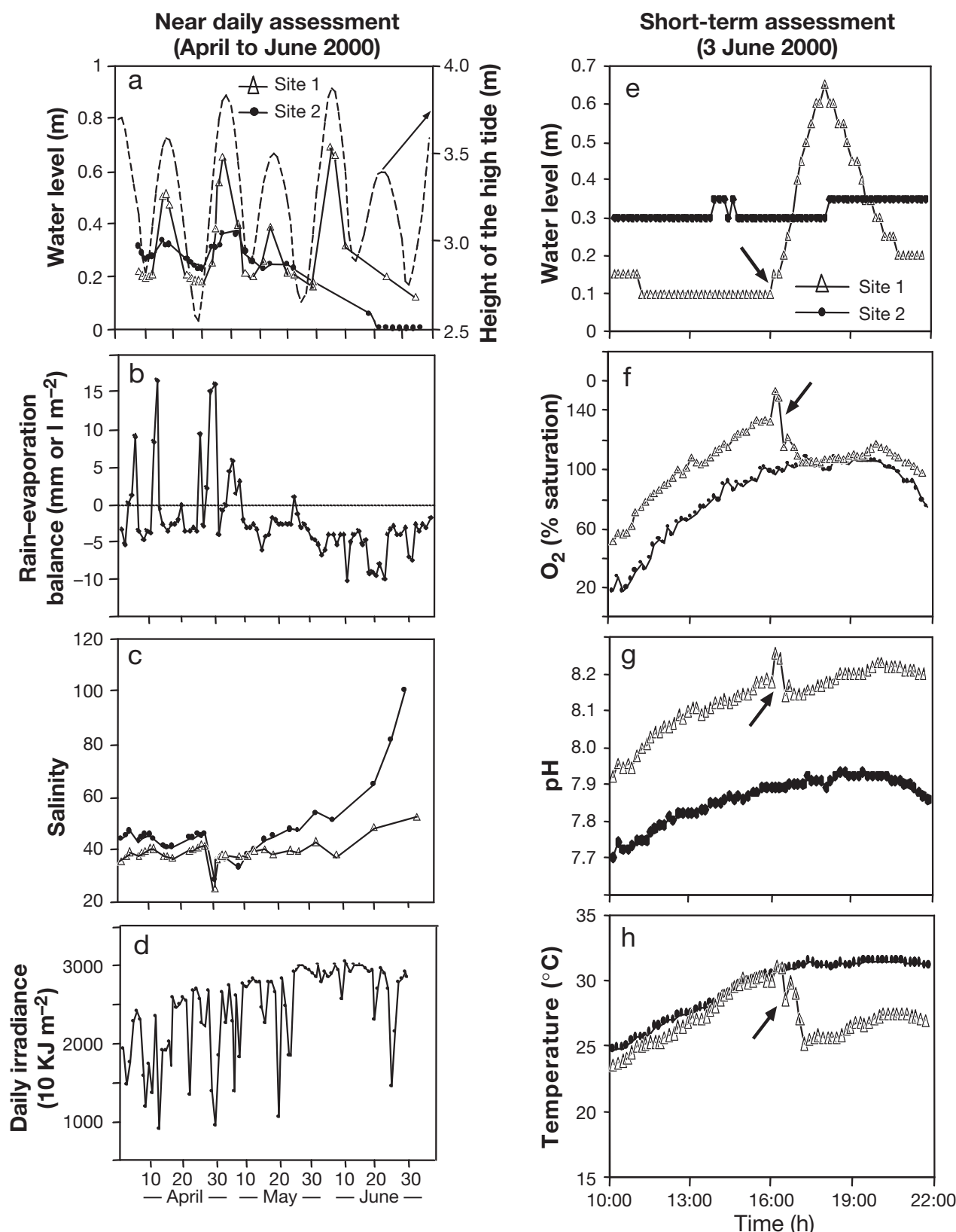

Fig. 2. $(\mathrm{a}-\mathrm{d})$ Long-term and $(\mathrm{e}-\mathrm{h})$ short-term changes in physico-chemical variables of the 2 locations of the lagoon. Monitoring of (a) water level, (b) rain-evaporation balance, (c) salinity and (d) daily irradiance was carried out on a nearly daily basis from April to June 2000. Assessment of (e) water level, (f) dissolved oxygen, (g) pH and (h) water temperature was done over a $12 \mathrm{~h}$ tidal cycle (3 June 2000). Dashed line in (a) represents the tidal height at the nearest reference station (Cadiz)

for fluffy and compact mats, respectively). However, this could be an artifact due to retention of portions of tangled cyanobacterial filaments in the biggest sieve.

\section{Types of microbenthic community and taxonomic composition}

Three different microbenthic communities were found at Site 2. Benthic pennate diatoms dominated the non-cohesive sediment located in the innermost part of the lagoon as the main taxonomic group among phototrophs. Pleurosigma, Nitzschia, Amphora and Navicula genera appeared frequently. Cyanobacteria were much scarcer than diatoms, but few and isolated colonies of Oscillatoria sp. and Spirulina sp. (Oscillatoriales), with gliding motility, were observed in the lax, light-brown surface of the sediment.

Fluffy mats usually presented several well-defined layers. Different taxonomic groups appeared vertically 
segregated in the mat, forming different coloured layers. Pennate diatoms, mainly Nitzschia spp., Navicula spp. and Amphora spp., dominated the upper golden layer. Striatella unipunctata was also abundant at some isolated points. Fluffy tufts (Fig. 3b) were formed by the diatoms previously mentioned and some filamentous cyanobacteria, like Oscillatoria sp. Below this fluffy, golden layer, a green band dominated by cyanobacteria was found, with Microcoleus chthonoplastes (Oscillatoriales) as the dominant species. Gloeocapsa and Chroococcus turgidus (order Chroococcales) were also found. A thin white band of ca. $100 \mu \mathrm{m}$ dominated by the filamentous, motile colourless sulfur bacterium Beggiatoa sp. was observed below the cyanobacterial layer. A $200 \mu \mathrm{m}$ thick purple layer and a thin hard crust could be observed before reaching the black sediment.

The compact mat usually appeared to be associated with the upper border of the lagoon, and it was thinner than the fluffy mats. A diatom layer was not observed. The photosynthetic community was mainly composed of the filamentous cyanobacteria Microcoleus chthonoplastes, which formed a dense and highly compact mat (Fig. 3c). Below this band, a thin white band composed of Beggiatoa and a thin purple layer could be observed before reaching the black sediment.

\section{Vertical distribution of pigments and organic matter}

The vertical structure of the photosynthetic community was significantly different among the 3 benthic communities ( $p<0.001,2$-factor ANOVA). In the sediment and the compact mat, maximum chl a concentrations were found in the uppermost layer, while in the fluffy mat they were found between 3 and $5 \mathrm{~mm}$ depth (Fig. 7a). This subsurface chl a maximum coincided

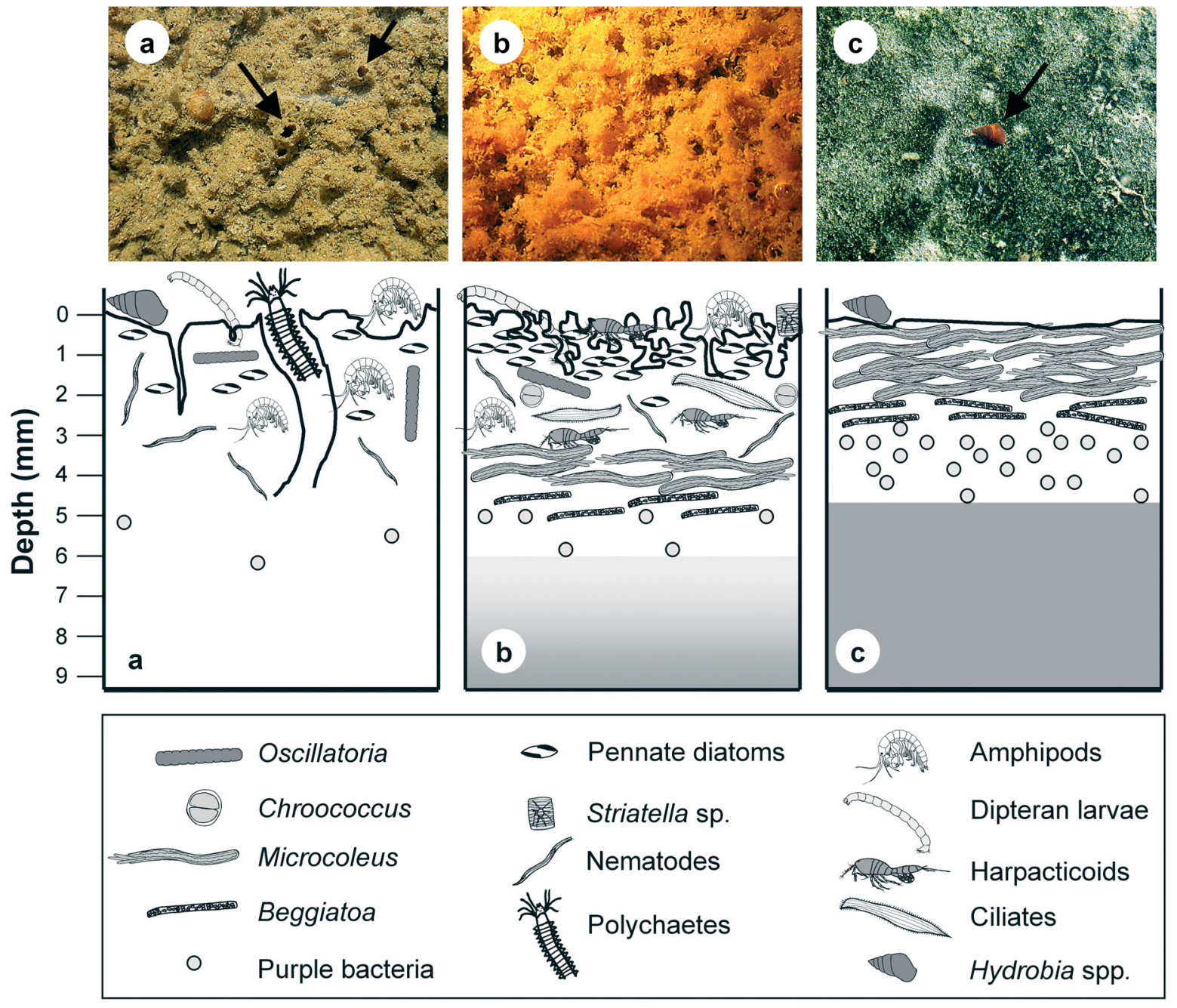

Fig. 3. Surficial appearance of the 3 benthic communities studied. (a) Sediment without mat, where some polychaete tubes can be observed (arrows), (b) fluffy microbial mat, and (c) compact-laminated microbial mat with a gastropod (Hydrobia ulvae) migrating during flooding (arrow) 


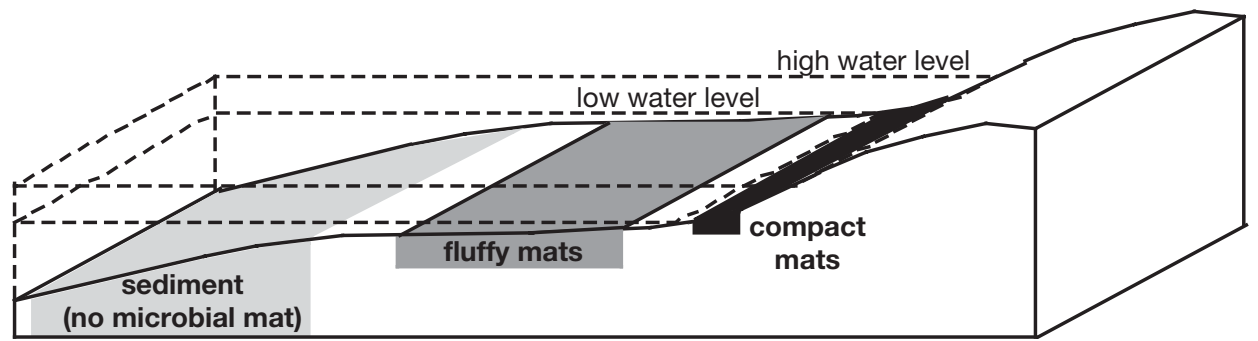

Fig. 4. Zonation of the 3 different microbenthic communities along a shore profile with the presence of a dense layer of Microcoleus chthonoplastes at this depth. Mean values were also significantly different ( $p<0.025$, ANOVA) among communities $\left(14.7 \mu \mathrm{g} \mathrm{chl} \mathrm{a} \mathrm{g}^{-1} \mathrm{ww}\right.$ in the sediment and 63.9 and $66.2 \mu \mathrm{g} \mathrm{chl} \mathrm{a} \mathrm{g} \mathrm{g}^{-1}$ ww for the fluffy and the compact mats, respectively), but significant differences only existed between the sediment and both mats ( $p<0.001$, Tukey test). However, maximum surface values in the compact mat were 2 -fold higher than in the subsurface maximum present in the fluffy mat, and even 4 to 5 times higher when the upper layers of both mats were compared (Fig. 7a). Maximum bacteriochlorophyll a concentrations were found below the maximum chl a concentrations in the 3 communities, but they were much higher in the compact mat than in the sediment and the fluffy mat (Fig. 7b).

Differences in the vertical structure of microbenthic communities were evident in their organic matter and water contents (Fig. 8). A lower organic content was present in the sediment (Fig. 8a), while both mats (fluffy and compact) showed greater amounts of

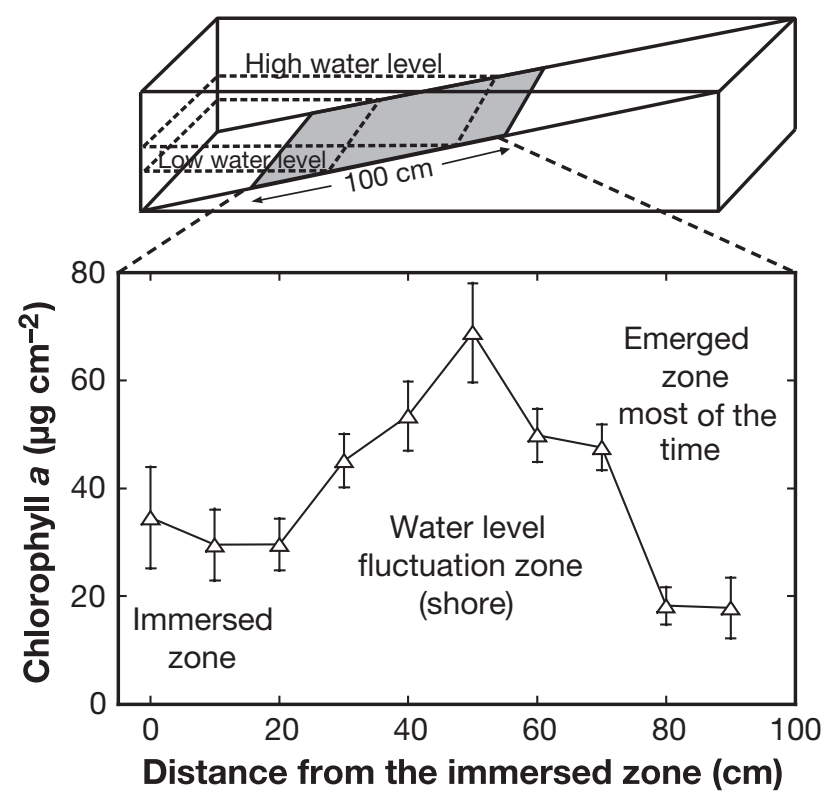

Fig. 5. Benthic chlorophyll a distribution along a steep shore. Each point corresponds to the mean value of 3 samples. Error bars represent $\pm \mathrm{SD}$ organic content (Fig. 8a), mainly associated with the surface, where diatoms and cyanobacteria accumulate. Water content analysis also showed some differences between the benthic communities studied, with a higher amount of water in the fluffy mat (Fig. 8b), which could be related to its plenty-of-tufts fluffy structure.

\section{Vertical microgradients of $\mathrm{O}_{2}$, sulfide and $\mathrm{pH}$}

Vertical distribution of $\mathrm{O}_{2}$ in light significantly differed among communities ( $\mathrm{p}<0.001,2$-factor ANOVA). The highest $\mathrm{O}_{2}$ penetration and oxygen concentrations were detected in the fluffy microbial mat, where an oxygen subsurface maximum (values up to $1100 \mu \mathrm{M}$ ) was found at 3.5 to $6 \mathrm{~mm}$ depth. The sediment and the compact mat presented very similar maximum concentrations of oxygen, of ca. $800 \mu \mathrm{M}$ (Fig. 9a), despite having quite different chl a concentrations (Fig. 7); these $\mathrm{O}_{2}$ maxima were shallower than in the fluffy mat, and they were located at similar depths. However, $\mathrm{O}_{2}$ penetration was 2-fold higher in the diatom-dominated sediment compared with the compact microbial mat. Maximum oxygen concentrations in both the fluffy and the compact mats were associated with a layer dominated by Microcoleus chthonoplastes. In the dark, the oxic layer was strongly reduced in all 3 communities,

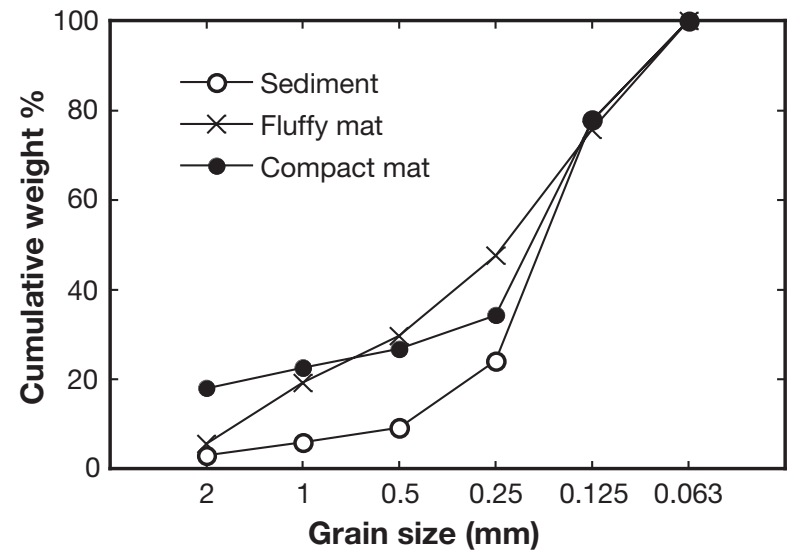

Fig. 6. Granulometric curves of the 3 microbenthic communities studied 
Fig. 7. Vertical distribution of (a) chlorophyll $a$ and (b) bacteriochlorophyll $a$ in the 3 communities studied. Each point corresponds to the mean value of 3 samples. Error bars represent \pm SD. ww: wet weight
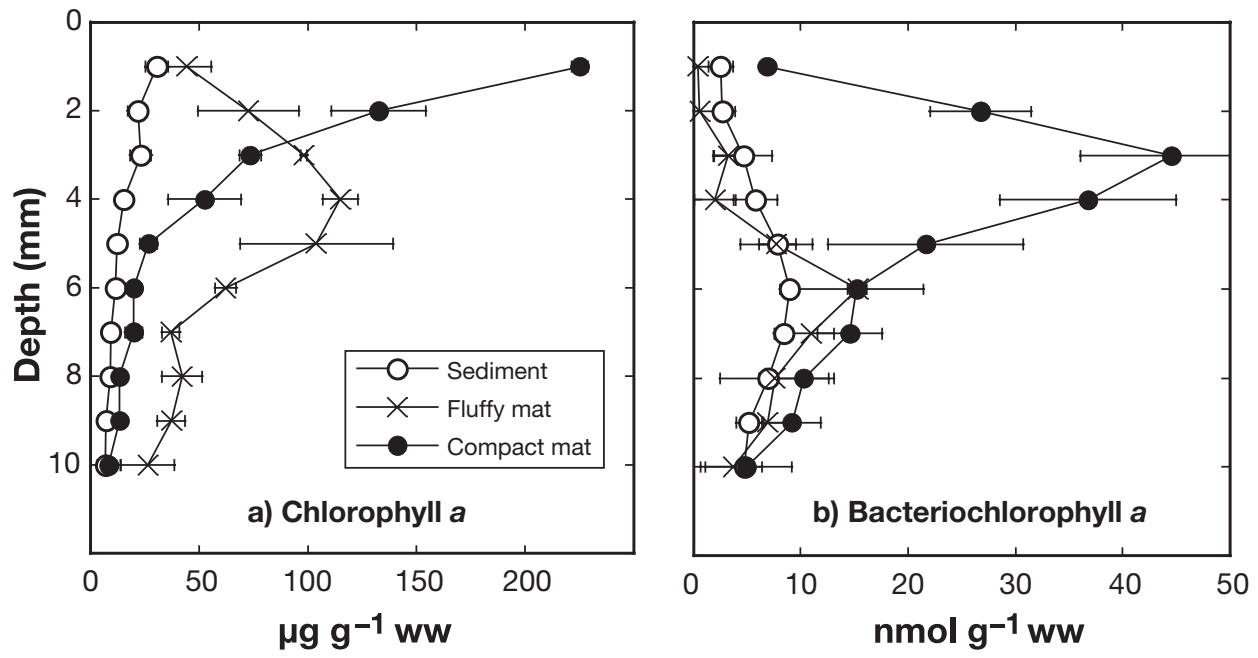

reaching very similar depths: $1 \mathrm{~mm}$ in the sediment and $0.7 \mathrm{~mm}$ in the compact mat (Fig. 9d). The maximum difference between light and dark conditions occurred in the fluffy mat, with a drastic reduction from 10 to $1.7 \mathrm{~mm}$.

Areal net photosynthesis rate calculated from the $\mathrm{O}_{2}$ profiles at the diffusive boundary layer in light represents the oxygen exportation to the overlying water $\left(J_{\text {up }}\right)$, and was highest for the compact mat $(0.35 \mu \mathrm{mol}$ $\left.\mathrm{O}_{2} \mathrm{~cm}^{-2} \mathrm{~h}^{-1}\right)$. A somewhat lower rate was estimated for the sediment $\left(0.2805 \mu \mathrm{mol} \mathrm{O}_{2} \mathrm{~cm}^{-2} \mathrm{~h}^{-1}\right)$ and the lowest rate was estimated for the fluffy mat $\left(0.1403 \mu \mathrm{mol} \mathrm{O}_{2}\right.$ $\mathrm{cm}^{-2} \mathrm{~h}^{-1}$ ) (Table 1). The oxygen exportation obtained in the compact mat could be expected by taking into account that chl a concentration was highest in this community. However, minimum values found in the fluffy mat were unexpected, as maximum oxygen concentrations of up to $1100 \mu \mathrm{M}$ were found (see 'Discussion'). The flux of $\mathrm{O}_{2}$ produced in the community photic layer that diffuses downward $\left(J_{\text {down }}^{\prime}\right)$ was highest for the compact mat $\left(0.112 \mu \mathrm{mol} \mathrm{O} \mathrm{O}_{2} \mathrm{~cm}^{-2} \mathrm{~h}^{-1}\right)$, indicating that both the highest net photosynthesis and the highest oxygen consumption below the photic layer occurred in this mat. The lowest $J_{\text {down }}^{\prime}$ values were estimated in the fluffy mat $\left(0.03 \mu \mathrm{mol} \mathrm{O} \mathrm{O}_{2} \mathrm{~cm}^{-2} \mathrm{~h}^{-1}\right)$ (Table 1). These results are again surprising, considering that both microbial mats were similar in the layer where $J_{\text {down }}^{\prime}$ was calculated. A layer of Microcoleus chthonoplastes above the Beggiatoa layer and the purple bacteria was found at 7 to $9 \mathrm{~mm}$ in the fluffy mat and at 1.5 to $2 \mathrm{~mm}$ in the compact mat, where $J_{\text {down }}^{\prime}$ was calculated for each community. Areal respiration in the dark $\left(R_{\text {dark }}\right)$ was maximum for the diatomdominated sediment $\left(0.15 \mu \mathrm{mol} \mathrm{O}_{2} \mathrm{~cm}^{-2} \mathrm{~h}^{-1}\right)$, somewhat lower for the fluffy mat $\left(0.12 \mu \mathrm{mol} \mathrm{O}_{2} \mathrm{~cm}^{-2} \mathrm{~h}^{-1}\right)$, and the lowest rate was calculated in the compact mat $\left(0.10 \mu \mathrm{mol} \mathrm{O} \mathrm{Cm}^{-2} \mathrm{~h}^{-1}\right)$ (Table 1).
In the light, $\mathrm{pH}$ profiles corresponded with oxygen profiles, with the highest pHs, generally, at the same depths as the highest oxygen concentrations (Fig. 9a,c). Maximum pH values of 9.6 and 10.5 were measured in the fluffy and the compact mats, respectively (Fig. 9c). In the dark, pH remained constant in both the sediment and the fluffy mat, while in the compact mat a relatively steep decrease was observed (Fig. 9f).

Sulfide was not detected in the upper $9 \mathrm{~mm}$ in the diatom-dominated sediment (Fig. 9b,e). In the fluffy mat, some sulfide was measured from $8 \mathrm{~mm}$ downward only in the dark (Fig. 9e). In the compact mat, increasing concentrations with depth (up to $500 \mu \mathrm{M}$ ) were found in both light and dark. However, the oxygen-sulfide transition layer was pushed downward in light as the result of photosynthetic $\mathrm{O}_{2}$ production. (Fig. 9b,e). Apparent rates of sulfate reduction for the compact mat, calculated from the sulfide profiles, reached 0.084 and $0.0798 \mu \mathrm{mol}$ $\mathrm{cm}^{-2} \mathrm{~h}^{-1}$ in light and dark, respectively (Table 1).

The degree of compactness of each community is clearly reflected in the product $\phi \times D_{\mathrm{s}}$, which express diffusivity (Table 1). As expected, minimum values of $\phi \times D_{\mathrm{s}}$ were found in the compact mat. The highest value of $\phi \times D_{\mathrm{s}}$ was observed in the fluffy mat, revealing that the compactness of the fluffy mat was even lower $\left(0.921 \times 10^{-5} \mathrm{~cm}^{2} \mathrm{~s}^{-1}\right)$ than that of the sediment $\left(0.789 \times 10^{-5} \mathrm{~cm}^{2} \mathrm{~s}^{-1}\right)$. The water content in the upper $2 \mathrm{~mm}$ and $\mathrm{O}_{2}$ penetration depth were positively correlated with diffusivity (Fig. 10a,b). Meiofaunal abundance and diffusivity seems to be positively related although large changes in diffusivity between the compact mat and the diatom-dominated sediment were not matched by a similar increase in meiofauna (Fig. 10c). However, the large abundance of macrofauna in the diatom-dominated sediment might be responsible for the relatively high diffusivity measured in this community (Fig. 11a). 


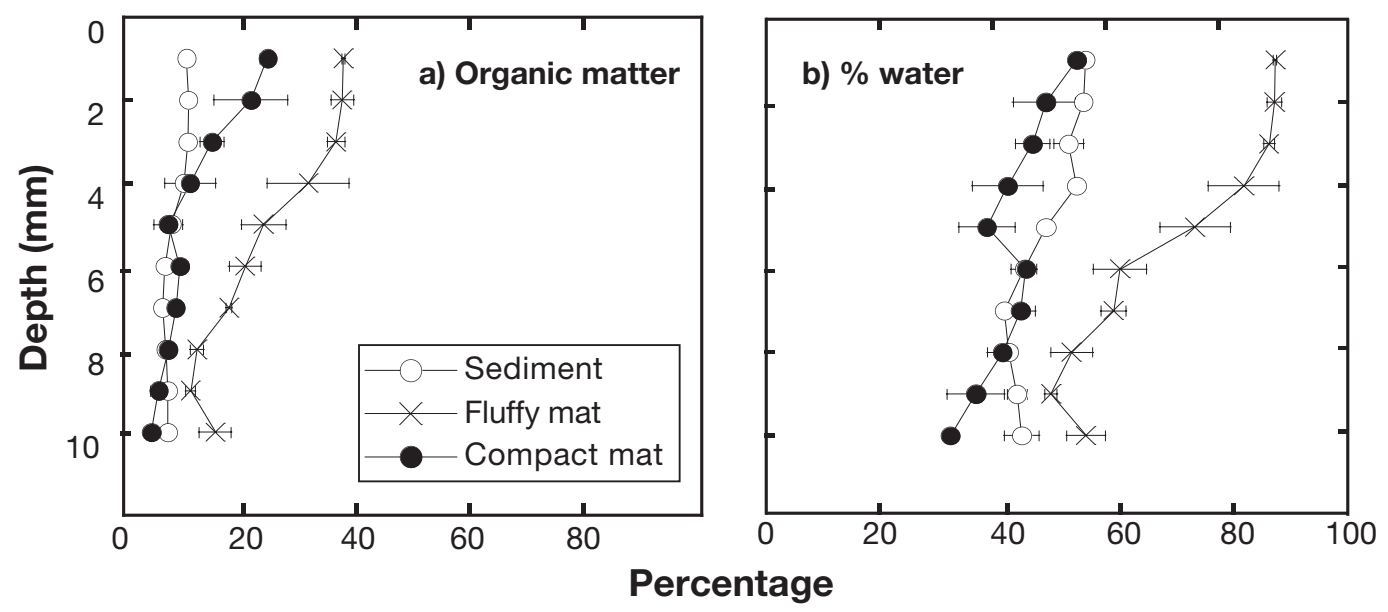

Fig. 8. Vertical distribution of (a) organic matter content and (b) water in the 3 communities studied. Each point corresponds to the mean value of 3 samples. Error bars represent $\pm \mathrm{SD}$

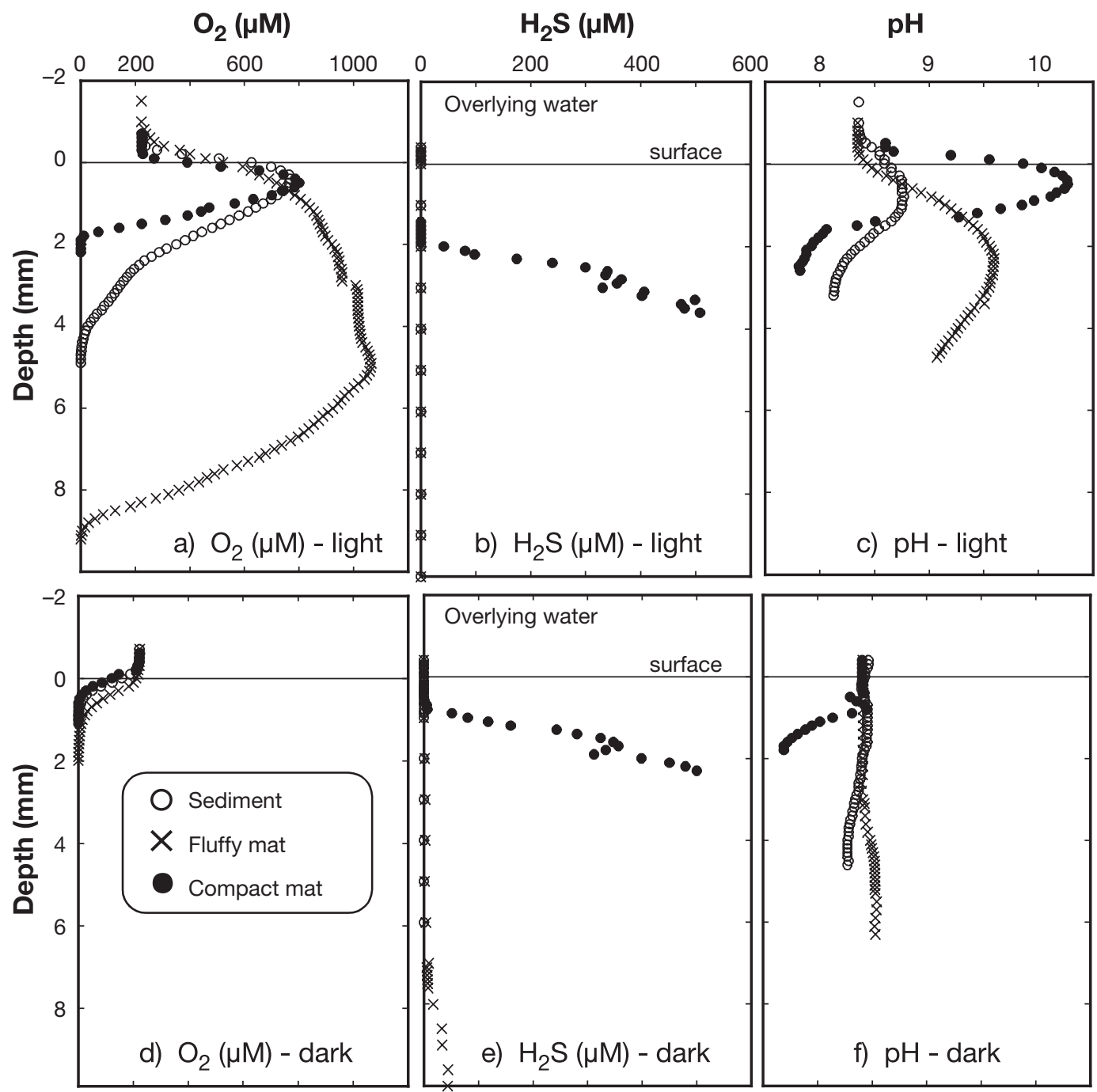

Fig. 9. Steady-state profiles of oxygen, $\mathrm{H}_{2} \mathrm{~S}$ and $\mathrm{pH}$ in the 3 benthic communities studied (a-c) illuminated with $220 \mu \mathrm{mol}$ photons $\mathrm{m}^{-2} \mathrm{~s}^{-1}$ and $(\mathrm{d}-\mathrm{f})$ in darkness. Each profile is the mean of 2 to 5 measurements. Error bars are not presented for clarity 

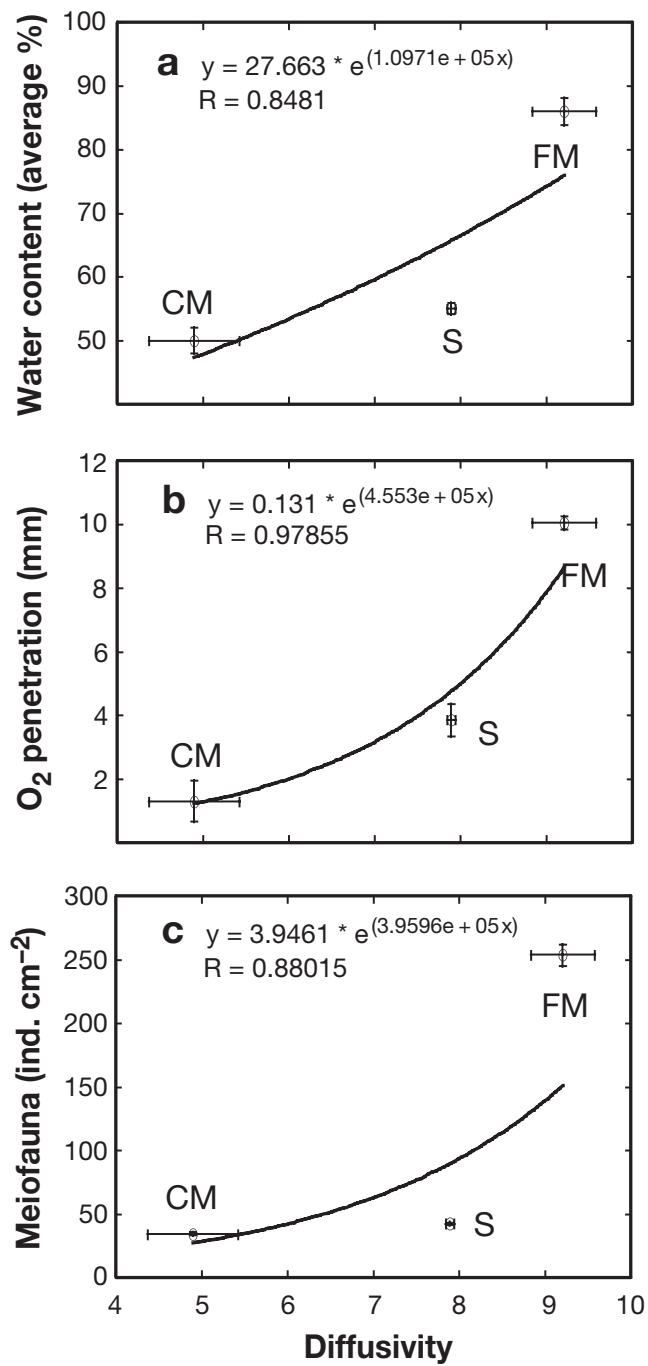

Fig. 10. Correlations between diffusivity and (a) water content, (b) oxygen penetration depth, and (c) meiofauna in the 3 benthic communities studied. Exponential fits (fine line) are represented in all cases. CM: compact mat; FM: fluffy mat; S: sediment

\section{Meiofauna and macrofauna}

Several different taxonomic groups of meiofaunal organisms were found: nematodes, harpacticoid copepods, amphipods (juvenile), polychaetes and large ciliates $(>300 \mu \mathrm{m})$. In the fluffy mat, meiofaunal abundance was very high (mainly nematodes and harpacticoids) in comparison to sediment and the compact mat, where meiofaunal abundance was very low (Fig. 11a). The concentration of nematodes was 8-fold higher in the fluffy mat than in the sediment, while harpacticoids were only found in the fluffy mat $\left(0.51 \times 10^{6}\right.$ ind. $\left.\mathrm{m}^{-2}\right)$. Abundances of nematodes and harpacticoids were significantly different among the different communities $(\mathrm{p}<0.001$, ANOVA).
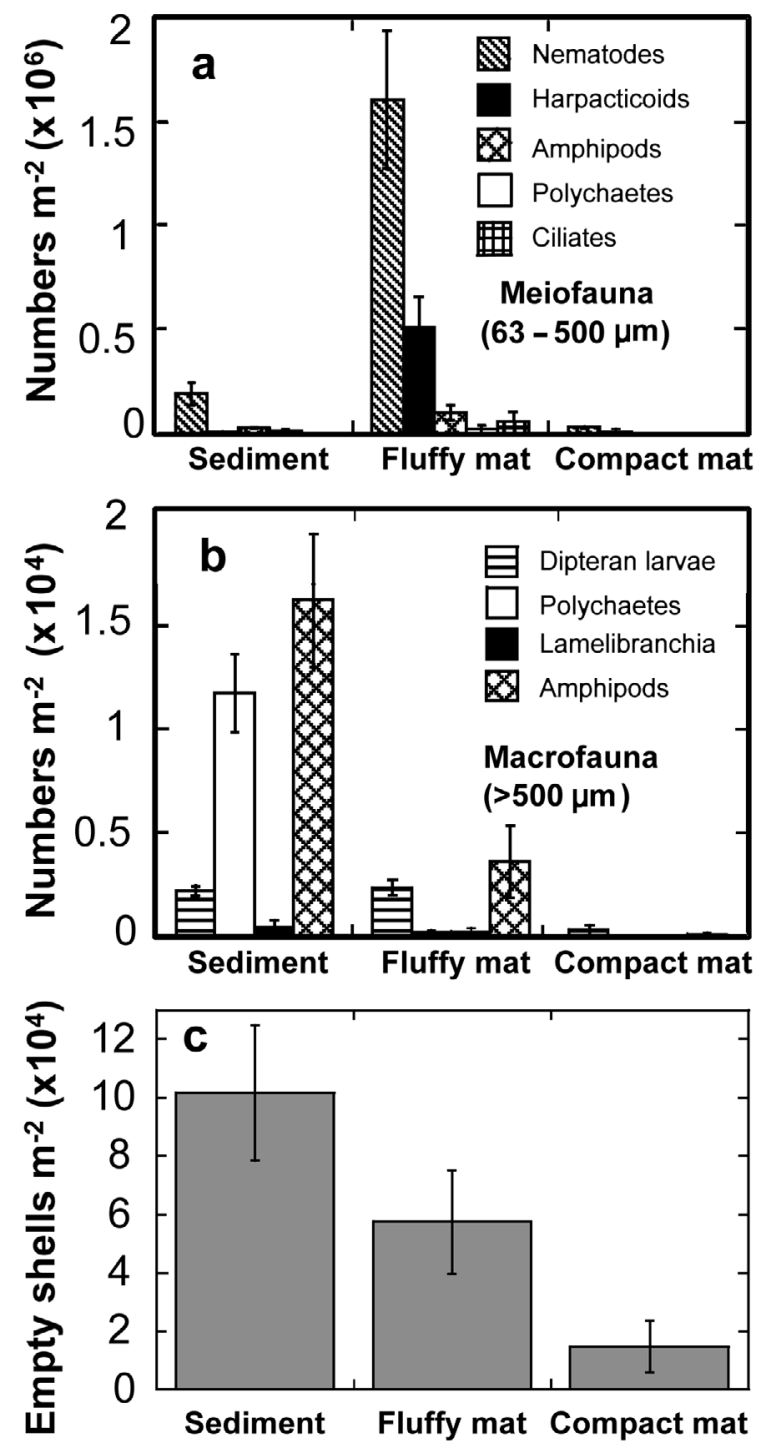

Fig. 11. Abundance of (a) meiofauna and (b) macrofauna per $\mathrm{m}^{2}$ and (c) empty shells from Hydrobia ulvae and H. minoricensis. Each bar represents the mean value of 3 samples. Error bars represent \pm SD

Four different groups of macroorganisms were found: dipteran larvae (Chironomus salinarius and Halocladius varians), polychaetes (Capitella capitata and Nereis diversicolor), Lamellibranchia (Cerastoderma glaucum) and amphipods (Cymadusa filosa, Microdeutopus gryllotalpa and Melita palmata) (Fig. 11b). No living gastropods were found, but a large number of empty shells from Hydrobia minoricensis and $H$. ulvae were present (Fig. 11c), especially in the bare sediment, indicating that this group can temporarily colonize this habitat. Polychaetes were only present in sediment $\left(1.17 \times 10^{4}\right.$ ind. $\left.\mathrm{m}^{-2}\right)$, while dipteran larvae were as abundant in the sediment as in the fluffy mat 
$\left(2 \times 10^{3}\right.$ ind. $\left.\mathrm{m}^{-2}\right)$ (Fig. 11b). However, the main dipteran species in the sediment was the red $C$. salinarius, while $H$. varians (green in colour) only appeared in the fluffy mat. Amphipods were much more abundant in sediment (ca. $1.6 \times 10^{4}$ ind. $\mathrm{m}^{-2}$ ) than in the fluffy mat $\left(3.5 \times 10^{3}\right.$ ind. $\left.\mathrm{m}^{-2}\right)$. The most striking result was the absence of macrofauna in the compact mat. Abundances of amphipods, polychaetes, dipteran larvae, and numbers of Hydrobia spp. shells all differed significantly among the 3 communities ( $p<$ 0.003, ANOVA). Abundances of Lamellibranchia did not differ among communities $(p=0.26)$.

\section{DISCUSSION}

\section{Types of microbenthic communities and spatial distributions}

Well-developed microbial mats were mainly present at Site 2. Sites 1 and 2 differed considerably regarding physical forcing. Direct tidal influence at Site 1 controlled the water level and physico-chemical properties of the water column (Fig. 2). This regulation was apparent at short (within a day) and longer (weeks and months) time scales. In particular, daily tides kept salinity changes quite constant at Site 1, while salinity at Site 2 increased from April to the middle of June. Water balance over time was more complicated at Site 2 , where the entry of water from the San Pedro estuary was restricted to the very high tides and therefore changes in the rain-evaporation balance control the water level and salinity in this part of the lagoon that usually dries out in summer. These observations suggest that microbial mats develop either in sediments prone to episodic emersion or seasonal dry periods, or where hypersaline conditions are dominant for at least part of the year. Both frequent emersion periods and high salinity are the major differences between Sites 1 and 2 (Fig. 2a,c). The restriction of microbial mats to extreme environments has been repeatedly shown (Castenholz 1984, Pierson et al. 1987, Lassen et al. 1992, Wieland \& Kühl 2000). However, it is unclear whether the association between microbial mats and extreme conditions is a consequence of specific physiological adaptation of filamentous cyanobacteria dominating microbial mats, and/or because extreme conditions are limiting for grazers. Physiological adaptations to extreme abiotic factors could allow cyanobacteria to outcompete other taxonomic groups of primary producers like diatoms. However, the absence of microbial mats in more moderate conditions like those present at Site 1 is generally explained to be a result of colonization by meio- and macrofauna (Hargrave 1970, Connor et al. 1982). An experimental microcosm study reported that microbial mats only developed when potential grazers were excluded (Fenchel 1998).

Microbenthic communities found at Site 2, distinguishable to the naked eye (Fig. 3), were spatially distributed according to a very clear zonation pattern (Figs. 4 \& 5). From the lagoon center, the diatomdominated sediment, the fluffy microbial mat, and the compact microbial mat covered concentric zones located at progressively shallower water depths and, therefore, under increasing physical stress. These microbial communities were different in taxonomic composition, vertical organization, standing stock of autotrophic biomass, and also supported different abundances of meio- and macrofauna (Figs. 5, 7 \& 11).

Pennate diatoms dominated the oxygenic photosynthetic component of the sediment community of the inner part of the lagoon. Although some mat-forming microorganisms like Oscillatoria sp. and Spirulina sp. were present as isolated short colonies, this microbial community did not constitute mat consistency. The sediment grains, mainly fine sand, were not strongly bound either by mucus secretions or by the entangled framework of filamentous cyanobacteria as shown by the granulometric curve (Fig. 6). Standing stocks of photoautotrophic biomass and total organic matter content in sediment were the lowest of the communities studied (Figs. $7 \&$ 8). These values were somewhat larger than the range of concentrations found in many tidal flats in the upper first centimeter: 46 to $94 \mathrm{mg} \mathrm{chl}$ a $\mathrm{m}^{-2}$ in Netarts bay, USA (Davis \& McIntire 1983), 11

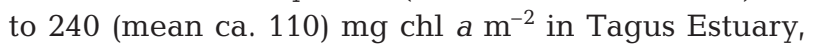
Portugal (Brotas et al. 1995) and ca. 3 to $20 \mathrm{mg}$ chl a $\mathrm{m}^{-2}$ in the Molenplaat, The Netherlands (Barranguet et al. 1997). Likely, the reduced erosion rate of sediment surface due to little water movement in this sheltered environment in comparison to a tidal flat could explain the relatively high photoautotrophic biomass of this diatom-dominated microbial community.

Closer to the lagoon fringe, the diatom-dominated community was replaced by a fluffy microbial mat. This seems to be mainly a transition community between the diatom-dominated sediment and the compact microbial mat dominated by cyanobacteria. The 2 major characteristics of the fluffy mat were the presence of a diatom layer with some Oscillatoria sp. filaments on a deeper Microcoleus band, and the fluffy consistency of the diatom layer. Diatom species found in the fluffy mat were similar to those found in the diatom-dominated sediment, suggesting a possible colonization from sediment. The presence of a golden diatom layer on cyanobacteria-dominated microbial mats is relatively common (Jørgensen et al. 1983, Pierson et al. 1987, Lassen et al. 1992), but the ecological factors that determine its presence are not clear. It is likely that in our system, diatom colonization of the compact microbial 
mats at the lagoon fringe is limited by the lower resistance of diatoms to drought stress compared to matforming cyanobacteria. Although the diatom layer is frequently observed in microbial mats, the extreme fluffy consistency found here is less common. It is likely that such a fragile 3D structure can persist only under quiescent hydrodynamic conditions, such as those that occur within the lagoon. This structure considerably increases the fractal dimension at the water-sediment interface, therefore increasing the surface for mass exchange. Biofilms grown under conditions of low flow velocity spontaneously develop a spongy architecture with voids and channels where mass transfer is no longer exclusively by molecular diffusion (Røy et al. 2002). In addition, its 3-dimensional structure potentially creates many new ecological microniches (Raffaelli \& Hawkins 1996), which may explain the much higher abundance of meiofauna in the fluffy microbial mats compared with the diatom-dominated sediment and the compact microbial mat. Alternatively, meiofaunal activity could also have contributed to the observed structure (Huettel \& Gust 1992), which may remain because of low shear stress and turbulence existing at Site 2.

The compact microbial mat, dominated by Microcoleus chthonoplastes, was restricted to the lagoon fringe, where periodic emersion and desiccation are more likely. $M$. chthonoplastes has a variety of physiological adaptations to drought stress: the production of UV-protective substances (Garcia-Pichel \& Castenholz 1991), compatible solutes (Karsten 1996), capsular exopolymeric substances (De Winder et al. 1999), and a higher competitive success at high temperature relative to diatoms (Waterman et al. 1999) are some examples. In addition, the very low abundance of meio- and macrofauna in the lagoon fringe likely contributed to the preservation of the compact mat structure. Below the $M$. chthonoplastes layer, the vertical community structure of both types of mats were very similar. Despite having very different vertical distributions of photoautrophic biomass (Fig. 7), both types of mats had similar concentrations of chl a per surface unit.

Meio- and macrofaunal abundance probably also influences microbenthic community composition in every zone. Benthic fauna are in turn critically controlled by hydric stress. Macrofauna was almost absent from the area covered by compact microbial mats, but reached maximal densities in the innermost part of the lagoon covered by loose sediment (Fig. 11). Although at the time of sampling no living gastropods were found, the number of empty Hydrobia spp. shells suggests either a preference for the permanently immersed zone, or an accumulation of corpses in deeper areas where water remains for a longer time. In contrast, meiofauna were more abundant in the fluffy mat, with nematodes and harpacticoid copepods being the most abundant taxonomic groups. Both macrofauna and meiofauna abundances were low in the lagoon fringe where the water level was lower and the risk of desiccation higher.

\section{Community structure and function}

Differences in the vertical structure and species composition of the microbenthic communities considerably affected their net metabolism and the mass exchange at the water-sediment interface. These differences were manifested in the vertical profiles of $\mathrm{O}_{2}$, $\mathrm{pH}$ and $\mathrm{H}_{2} \mathrm{~S}$ among the 3 types of communities. Microelectrode measurements in the 3 communities were done under identical experimental conditions, including temperature, irradiance, and flow velocity, which allowed for direct comparison of measured profiles, and the process rates derived from them. The different structures of the 3 communities were reflected in the measured diffusivities. In the compact mat, diffusivity was the lowest, while in the fluffy mat it was the highest. Assuming the same oxygen concentration in the water column, oxygen penetration depth in the dark depends directly on diffusivity and inversely on the oxygen consumption rate within the sediment (Revsbech et al. 1980, Rasmussen \& Jørgensen 1992). In summary, the fluffy mat was characterized by the highest diffusivity coefficients, $\mathrm{O}_{2}$ penetration and $\mathrm{O}_{2}$ consumption rates, while the compact mat showed the lowest ones.

The oxygen penetration depth in the light in sediments inhabited by photosynthetic communities depends strongly on incident photon flux density. In the light, photosynthetic oxygen production considerably increases the oxygen availability in the sediment and the oxygen penetrates down to deeper layers (Jørgensen et al. 1983). It is possible that photon flux density used in this study $\left(220 \mu \mathrm{mol}\right.$ photons $\left.\mathrm{m}^{-2} \mathrm{~s}^{-1}\right)$ was not saturating, but since it was identical during light measurements for the 3 communities, it is interesting to compare the differences found between dark and light. The fluffy microbial mat showed the biggest differences between oxygen penetration depth in the light $(10 \mathrm{~mm})$ and in the dark $(1.8 \mathrm{~mm})$. This $8.2 \mathrm{~mm}$ difference represents an important contribution of the oxygenic photosynthetic community to the volume of aerobic sediment during daytime, where the oxidation of organic matter is carried out by aerobic respiration. Lower values were measured for the diatomdominated sediment $(3.9 \mathrm{~mm})$ and the compact microbial mat $(1.3 \mathrm{~mm})$, which were similar to those reported in the literature for these types of communities (Jørgensen et al. 1983, Wieland \& Kühl 2000). At a given 
photon flux density, oxygen penetration depends on the net photosynthetic rate in the photic layer, the oxygen consumption rate (including both biotic and abiotic processes) in the deepest layer, and on the sediment diffusivity. The structure of the fluffy microbial mat was responsible for a high diffusivity and probably led to a considerably deeper penetration of light, which caused a much deeper $\mathrm{O}_{2}$ penetration in the light than for the other communities.

Below the oxic layer, mineralization of the organic matter depends upon the availability of electron acceptors other than $\mathrm{O}_{2}$. In marine sediments, sulphate reduction is the major anaerobic processes to complete the oxidation of organic matter (Jørgensen 1982). Our results show important differences among the 3 benthic microbial communities regarding dissolved sulphide concentration within the sediment (Fig. 10). Sulphide was not detected in the diatom-dominated sediment in the upper $9 \mathrm{~mm}$ in the light or in the dark. In the fluffy mat, small amounts of $\mathrm{H}_{2} \mathrm{~S}$ were only detected below $8 \mathrm{~mm}$ in the dark when photosynthetic activity was suppressed. However, high $\mathrm{H}_{2} \mathrm{~S}$ concentrations were measured in the compact mat below the oxic layer both in the light and dark. Sulphate reduction in coastal sediments is mainly controlled by temperature and the input of organic matter (Moeslund et al. 1994). Since the experimental conditions for the microelectrodes measurement were identical, temperature cannot explain the observed differences in $\mathrm{H}_{2} \mathrm{~S}$ concentration. Therefore, the absence of $\mathrm{H}_{2} \mathrm{~S}$ in the diatom-dominated sediment is likely related to its lower organic-matter content (Fig. 8). Different reoxidation rates could also occur among communities, since the $\mathrm{O}_{2}$ penetration depth was also different in light. Dissolved sulphide is not usually found close to the surface in low-organic coastal sediments, where the reoxidation with $\mathrm{Fe}$ and $\mathrm{Mn}$ is rapid (Moeslund et al. 1994, Thamdrup et al. 1994). However, the usual presence of $\mathrm{H}_{2} \mathrm{~S}$ in microbial mats is due to the high accumulation of biomass per unit of volume and to their relatively high primary production rates (Cohen \& Rosenberg 1989, Kühl \& Jørgensen 1992). Both conditions were observed in the compact microbial mat, where areal net photosynthesis rate and oxygenic photosynthetic biomass was higher than in other sediment types (Table 1, Fig. 7). The fluffy mat contained only slightly lower integrated chl a and a larger content of organic matter (Figs. $7 \& 8$ ); however, areal net photosynthesis rate was the lowest (Table 1). In the fluffy and compact mats, the presence and the position of the $\mathrm{H}_{2} \mathrm{~S}-\mathrm{O}_{2}$ interface was associated with the white layer dominated by the sulphide oxidizing bacteria Beggiatoa. This layer was more developed in the compact mat and was absent in the diatom-dominated sediment, where no $\mathrm{H}_{2} \mathrm{~S}$ was detected.

\section{Food chains from microbenthic communities}

Primary production by microphytobenthos is the essential energy and organic carbon source for the heterotrophic community inhabiting the lagoon. Besides being a very shallow environment, the mean chl a concentrations in the water column during the same period shown in Fig. 2 were 3.05 and $1.45 \mu \mathrm{g} \mathrm{chl} \mathrm{a} \mathrm{l}^{-1}$ for Sites 1 and 2, respectively (results not shown). Assuming a mean depth of $0.5 \mathrm{~m}$, the integrated chl a concentrations in the water column, 1.52 and $0.72 \mathrm{mg}$ $\mathrm{chl} \mathrm{a} \mathrm{m}^{-2}$, were more than 2 orders of magnitude lower than those measured in the benthic communities studied, ranging from 172 to $721 \mathrm{mg} \mathrm{m}^{-2}$ for the diatomdominated community and the compact microbial mat, respectively. Phytoplankton biomass was likely limited by the low inorganic nutrient concentration in the water column. Therefore, the balance between photosynthesis and respiration by the benthic microbial community seems primarily responsible for the observed daily changes in $\mathrm{O}_{2}$ saturation and $\mathrm{pH}$ in the water column at both sites (Fig. 2). However, it is difficult to assess the relative contribution of each community, since they have different chl a concentrations and meio- and macrofaunal abundances.

Given their differences in photoautotrophic biomass, the 3 communities are likely to have different contributions to the total primary production of the system. In addition, the fraction of the fixed $C$ that will be recycled within each microbial community or exported to higher trophic levels seems to differ between communities as well. Comparison of net photosynthesic carbon fixation rate and aerobic respiration rate in the dark provides insight into the fate of fixed $\mathrm{C}$ for each community and how much will be available for higher trophic levels. In the diatom-dominated sediment, net carbon fixation during the light period was $40.1 \mu \mathrm{g} \mathrm{C}$ $\mathrm{cm}^{-2} \mathrm{~d}^{-1}$, while dark respiration was $21.6 \mu \mathrm{g} \mathrm{C} \mathrm{cm}{ }^{-2} \mathrm{~d}^{-1}$ and thus the daily net primary production was $18.5 \mu \mathrm{g}$ $\mathrm{C} \mathrm{cm}^{-2} \mathrm{~d}^{-1}$. This daily net primary production did not accumulate in the sediment because both photosynthetic biomass and organic matter content in the sediment were the lowest of the 3 communities. Given the abundance of macrofauna in the diatom-dominated sediment, it is likely that a large fraction of the daily net primary production is channelled to higher trophic levels. The flow of organic carbon to anaerobic mineralization was apparently low because no $\mathrm{H}_{2} \mathrm{~S}$ was detected in this community. The turnover rate for the photosynthetic component (P:B) can be approached by dividing the areal net photosynthesis rate by the photoautotrophic biomass, both expressed in carbon units. The P:B ratio for the oxygenic photosynthetic component was $0.09 \mathrm{~d}^{-1}$, the highest of the 3 communities investigated. 
Net photosynthetic carbon fixation in the fluffy microbial mat was relatively low, $20.2 \mu \mathrm{g} \mathrm{C} \mathrm{cm}^{-2} \mathrm{~d}^{-1}$, although this community had an areal standing stock of chl a (689 $\left.\mathrm{mg} \mathrm{chl} \mathrm{a} \mathrm{m}^{-2}\right)$ similar to that of the compact

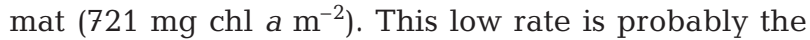
result of respiration by the abundant meiofauna inhabiting mostly the upper diatom layer. Dark respiration was $18 \mu \mathrm{g} \mathrm{C} \mathrm{cm}^{-2} \mathrm{~d}^{-1}$, and therefore the daily net primary production was only $2.2 \mu \mathrm{g} \mathrm{C} \mathrm{cm}^{-2} \mathrm{~d}^{-1}$. Given the abundance of meiofauna, they seem to be the major consumers of primary production in the diatom layer in the fluffy mat. In addition, high numbers of meiofauna may indirectly stimulate microphytobenthic production by enhancing nutrient availability and thus allowing a deeper penetration of light (Fenchel \& Straarup 1971, Jørgensen \& Des Marais 1986). Direct exploitation by meiofauna of primary production at the level of the Microcoleus chthonoplastes band, where the chl a maximum in this community was detected, is more unlikely due to periodic anoxia. Because meiofauna are known to be mainly restricted to the oxic layer in sediments (Knox 2000), it is likely that the existence of daily anaerobic conditions during the night at the level of the M. chthonoplastes layer prevented it from being grazed by meiofauna. The destiny of the fixed carbon in this layer is to either accumulate in the sediment or be mineralized anaerobically. The presence of sulphide in the dark indicates the activity of sulphatereducing bacteria. In addition, the fluxes of $\mathrm{O}_{2}$ at the mat-water interface might have been underestimated due to the fluffy architecture of the diatom layer. The structure of this layer, which includes many voids and channels, might have prevented molecular diffusion from being the dominant mass-transfer mechanism. We have some evidence of this because our attempts to measure gross primary production inside the fluffy diatom layer by the dark-light shift technique failed. This technique is based on Fick's second law of molecular diffusion (Kühl et al. 1996). If this was the case, both net photosynthesis rate and respiration in dark might have been underestimated.

The compact microbial mat presented the highest areal net photosynthesis rate. On a daily basis, the net carbon fixation rate was $50.5 \mu \mathrm{g} \mathrm{C} \mathrm{cm} \mathrm{Cd}^{-1}$. Only a fraction of this $\mathrm{C}$ was mineralized during the night: $14.4 \mu \mathrm{g} \mathrm{C} \mathrm{cm}^{-2} \mathrm{~d}^{-1}$. Since meio- and macrofauna were almost absent in the area covered by the compact microbial mat, the daily net primary production (36.1 $\mu \mathrm{g} \mathrm{C} \mathrm{cm}^{-2} \mathrm{~d}^{-1}$ ) was used in mat growth and/or oxidized by anaerobic processes. The importance of sulphate reduction as a mechanism of anaerobic mineralization of the organic carbon was evident from the high $\mathrm{H}_{2} \mathrm{~S}$ concentration found in this mat and, structurally, in the presence of a very conspicuous Beggiatoa layer.
Acknowledgements. This work was financially supported by grants MAT2000-0261, REN2002-01281/MAR, from the Ministerio de Ciencia y Tecnología, Spain. We acknowledge J. A. Muñoz, from Observatorio Meteorológico, for providing climatological data. The authors thank the reviewers for their helpful suggestions, which substantially improved the manuscript.

\section{LITERATURE CITED}

Aller RC, Aller Y (1992) Meiofauna and solute transport in marine muds. Limnol Oceanogr 37:1018-1033

Arias A, Drake P (1999) Fauna acuática de las salinas del Parque Natural Bahía de Cádiz. EGMASA, Seville

Awramik SM (1984) Ancient stromatolites and microbial mats. In: Cohen Y, Castenholz RW, Halvorson HO (eds) Microbial mats: stromatolites. AR Liss, New York, p 1-22

Barranguet C, Herman PMJ, Sinke JJ (1997) Microphytobenthos biomass and community composition studied by pigment biomarkers: importance and fate in the carbon cycle of a tidal flat. J Sea Res 38:59-70

Bourrelly P (1970) Les algues d'eau douce. Initiation à la systématique. I: Les algues bleues et rouges, les eugléniens, peridiniens et cryptomonadines. N Boubée \& Cie, Paris

Bourrelly P (1972) Les algues d'eau douce. Initiation à la systématique. II: Les algues vertes. N Boubée \& Cie, Paris

Bourrelly P (1981) Les algues d'eau douce. Initiation à la systématique. III: Les algues jaunes et brunes. Chrysophycées, phéophycées, xanthophycées et Diatomées. N Boubée \& Cie, Paris

Broecker WS, Peng TH (1974) Gas exchange rate between sea and air. Tellus 26:21-35

Brotas V, Cabrita T, Portugal A, Serodio J, Catarino F (1995) Spatio-temporal distribution of the microphybenthic biomass in intertidal flats of Tagus Estuary (Portugal). Hydrobiologia 300/301:93-104

Castenholz RW (1984) Composition of hot spring microbial mats: a summary. In: Cohen Y, Castenholz RW, Halvorson HO (eds) Microbial mats: stromatolites. AR Liss, New York, p 39-58

Castenholz RW, Gherna GL, Lewin R, Rippka R, Waterbury JB, Whitton BA (1989) Oxygenic photosynthetic bacteria. In: Staley JT, Bryant MP, Pfennig N, Holt JG (eds) Bergey's manual of systematic bacteriology, Vol 3. Williams \& Wilkins, Baltimore, MD, p 1710-1806

Chrétiennot-Dinet MJ (1990) Atlas du phytoplancton marin, Vol III: Chlorarachniophycées, chlorophycées, cryptophycées, euglenophycées, eustigmatophycées, prasinophycées, prymnésiophycées, rhodophycées et tribophycées. Centre National de la Recherch Scientifique, Paris

Cohen Y, Rosenberg E (1989) Microbial mats: physiological ecology of benthic microbial communities. American Society for Microbiology, Washington, DC

Connor MS, Teal JM, Valiela I (1982) The effect of feeding by mud snails, Ilyanass obsoleta (Say), on the structure and metabolism of a laboratory benthic algal community. J Exp Mar Biol Ecol 65:29-45

Cullen DJ (1973) Bioturbation in superficial marine sediments by interstitial meiobenthos. Nature 242:323-324

Davis MW, McIntire CD (1983) Effects of physical gradients on the production dynamics of sediment-associated algae. Mar Ecol Prog Ser 13:103-114

De Winder B, Staats N, Stal LJ, Paterson DM (1999) Carbohydrate secretion by phototrophic communities in tidal sediments. J Sea Res 42:131-146

de Wit R, van Gemerden H (1989) Growth responses of the 
cyanobacterium Microcoleus chthonoplastes with sulfide as an electron donor. In: Cohen Y, Rosenberg E (eds) Microbial mats: physiological ecology of benthic microbial communities. American Society for Microbiology, Washington, DC, p 320-325

Dubinin AV, Gerasimenko LM, Zavarzin GA (1992) Nitrogen fixation by cyanobacterium Microcoleus chthonoplastes from hypersaline lagoons of Lake Sivash. Mikrobiologya 61:593-597

Eaton JW, Moss B (1966) The estimation of numbers and pigment content in epipelic algal populations. Limnol Oceanogr 11:584-595

Epping EH, Khalili A, Thar R (1999) Photosynthesis and the dynamics of oxygen consumption in a microbial mat as calculated from transient oxygen microprofiles. Limnol Oceanogr 44:1936-1948

Fenchel T (1998) Formation of laminated cyanobacterial mats in the absence of benthic fauna. Aquat Microb Ecol 14: 235-240

Fenchel T, Straarup BJ (1971) Vertical distribution of photosynthetic pigments and the penetration of light in marine sediments. Oikos 22:172-182

Garcia-Pichel F, Castenholz RW (1991) Characterization and biological implications of scytonemin, a cyanobacterial sheath pigment. J Phycol 27:395-409

Giere O (1993) Meiobenthology. The microscopic fauna in aquatic sediments. Springer-Verlag, Berlin

Glud RN, Jensen K, Revsbech NP (1995) Diffusivity in surficial sediments and benthic mats determined by use of a combined $\mathrm{N}_{2} \mathrm{O}-\mathrm{O}_{2}$ microsensor. Geochim Cosmochim Acta 59: 231-237

Hargrave BT (1970) The effect of deposit-feeding amphipod on the metabolism of benthic microflora. Limnol Oceanogr 15:21-30

Holme NA (1971) Macrofauna sampling. In: Holme NA, McIntyre AD (eds) Methods for the study of marine benthos. Blackwell Scientific Publications, Oxford, p 80-130

Huettel M, Gust G (1992) Impact of bioroughness on interfacial solute exchange in permeable sediments. Mar Ecol Prog Ser 89:253-267

Jeroschewski P, Steuckart C, Kühl M (1996) An amperometric microsensor for the determination of $\mathrm{H}_{2} \mathrm{~S}$ in aquatic environments. Anal Chem 68:4351-4357

Joint IR (1978) Microbial production of an estuarine mudflat. Estuar Coast Mar Sci 7:185-195

Jørgensen BB (1982) Mineralization of organic matter in the sea bed-the role of sulphate reduction. Nature 296: 643-645

Jørgensen BB, Des Marais DJ (1986) A simple fiberoptic microprobe for high resolution light measurements: application in marine sediment. Limnol Oceanogr 31: 1376-1383

Jørgensen BB, Revsbech NP, Cohen Y (1983) Photosynthesis and structure of benthic microbial mats: microelectrode and SEM studies of four cyanobacterial communities. Limnol Oceanogr 28:1075-1093

Karsten U (1996) Growth and organic osmolites of geographically different isolates of Microcoleus chthonoplastes (Cyanobacteria) from benthic microbial mats: response to salinity change. J Phycol 32:501-506

Knox GA (2000) The ecology of seashores. CRC Press, New York

Komárek J, Anagnostidis K (1986) Modern approach to the classification system of cyanophytes 2-Chroococcales. Arch Hydrobiol Suppl 73:157-226

Komárek J, Anagnostidis K (1989) Modern approach to the classification system of cyanophytes 4-Nostocales. Arch
Hydrobiol Suppl 82:247-345

Krumgalz B, Fainshtein G (1989) Trace metal contents in certified reference sediments determined by nitric acid digestion and atomic absorption spectrometry. Anal Chim Acta 218:335-340

Kühl M, Jørgensen BB (1992) Microsensor measurements of sulfate reduction and sulfide oxidation in compact microbial communities of aerobic biofilms. Appl Environ Microbiol 58:1164-1174

Kühl M, Steuckart C, Eickert G, Jerochewski P (1998) A $\mathrm{H}_{2} \mathrm{~S}$ microsensor for profiling biofilms and sediments: application in an acidic lake sediment. Aquat Microb Ecol 15: 201-209

Kühl M, Glud RN, Ploug H, Ramsing NB (1996) Microenvironmental control of photosynthesis and photosynthesiscoupled respiration in an epilithic cyanobacterial biofilm. J Phycol 32:799-812

Lassen C, Ploug H, Jørgensen BB (1992) Microalgal photosynthesis and spectral scalar irradiance in coastal marine sediments of Limfjorden, Denmark. Limnol Oceanogr 37 : $760-772$

Li YH, Gregory S (1974) Diffusion of ions in sea water and in deep sea sediments. Geochim Cosmochim Acta 38:703-714

Lorenzen JR, Glud RN, Ploug H, Ramsing NB (1995) Impact of microsensor caused changes in diffusive boundary layer thickness on $\mathrm{O}_{2}$ profiles and photosynthetic rates in benthic communities of microorganisms. Mar Ecol Prog Ser 119:237-241

Moeslund L, Thamdrup B, Jørgensen BB (1994) Sulfur and iron cycling in a coastal sediment: radiotracer studies and seasonal dynamics. Biogeochemistry 27:129-152

Moezelaar R, Bijvank SM, Stal LJ (1996) Fermentation and sulfur reduction in the mat-building cyanobacterium Microcoleus chthonoplastes. Appl Environ Microbiol 62: $1752-1758$

Pierson B, Oesterle A, Murphy GL (1987) Pigments, light penetration, and photosynthetic activity in the multilayered microbial mats of Great Sipewisset Salt Marsh, Massachusetts. FEMS Microbiol Ecol 45:365-376

Pinckney JL, Carman KR, Lumsden SE, Hymel SN (2003) Microalgal-meiofaunal trophic relationships in muddy intertidal estuarine sediments. Aquat Microb Ecol 31: 99-108

Raffaelli D, Hawkins S (1996) Intertidal ecology. Chapman \& Hall, London

Rasmussen H, Jørgensen BB (1992) Microelectrode studies of seasonal oxygen uptake in a coastal sediment: role of molecular diffusion. Mar Ecol Prog Ser 81:289-303

Revsbech NP (1989) An oxygen microelectrode with a guard cathode. Limnol Oceanogr 34:474-478

Revsbech NP, Jørgensen BB (1986) Microelectrodes: their use in microbial ecology. In: Marshall KC (ed) Advances in microbial ecology, 9. Plenum, New York, p 293-352

Revsbech NP, Sorensen J, Blackburn TH, Lomholt JP (1980) Distribution of oxygen in marine sediments measured with microelectrodes. Limnol Oceanogr 25:403-411

Revsbech NP, Jørgensen BB, Blackburn TH, Cohen Y (1983) Microelectrode studies of photosynthesis and $\mathrm{O}_{2}, \mathrm{H}_{2} \mathrm{~S}$, and $\mathrm{pH}$ profiles of a microbial mat. Limnol Oceanogr 28: 1062-1074

Rippka R, Deruelles J, Waterbury JB, Herdman M, Stanier RY (1979) Generic assigments, strain histories and properties of pure cultures of Cyanobacteria. J Gen Microbiol 111: $1-61$

Round FE, Crawford RM, Mann DG (1990) The diatoms. Biology and morphology of the genera. Cambridge University Press, Cambridge 
Røy H, Hüttel M, Jørgensen BB (2002) The role of small-scale sediment topography for oxygen flux across the diffusive boundary layer. Limnol Oceanogr 47:837-847

Sournia A (1986) Atlas du phytoplancton marin, Vol I. Introduction, cyanophycées, dictyochophycées, dinophycées et raphidophycées. Centre National de la Recherche Scientifique, Paris

Staley JT, Bryant MP, Pfennig N, Holt JG (1989) Bergey's manual of systematic bacteriology, Vol 3. Williams \& Wilkins, Baltimore, MD

Thamdrup B, Fosing H, Jørgensen BB (1994) Manganese, iron and sulfur cycling in a coastal marine sediment, Aarhus Bay, Denmark. Geochim Cosmochim Acta 58:5115-5129

Thompson RC, Tobin ML, Hawkins SJ, Norton TA (1999) Problems in extraction and spectrophotometric determi-

Editorial responsibility: Kevin Carman,

Baton Rouge, Louisiana, USA nation of chlorophyll from epilithic microbial biofilms: towards a standard method. J Mar Biol Assoc UK 79: $551-558$

Van den Hoek C, Mann DG, Jahns HM (1995) Algae. An introduction to phycology. Cambridge University Press, Cambridge

Waterman F, Hillebrand H, Gerdes G, Krumbein WE, Sommer U (1999) Competition between benthic cyanobacteria and diatoms as influenced by different grain sizes and temperatures. Mar Ecol Prog Ser 187:77-87

Wieland A, Kühl M (2000) Short-term temperature effects on oxygen and sulfide cycling in a hypersaline cyanobacterial mat (Solar Lake, Egypt). Mar Ecol Prog Ser 196:87-102 Zar JH (1984) Biostatistical analysis, 2nd edn. Prentice-Hall, Englewood Cliffs, NJ

Submitted: January 6, 2004; Accepted: October 22, 2004

Proofs received from author(s): January 12, 2005 